\title{
Is energy security really too important to leave to markets?
}

Lawrence Haar, Oxford Brookes University

Email: Ihaar@brookes.ac.uk

\section{Abstract}

Involvement by government in the energy sector has historically been extensive. Generally, however, regulation and direct ownership have involved secondary sectors such as electricity generation and transport on the grounds that these are natural monopolies exhibiting increasing returns to scale. With some exceptions, primary energy production has been left in private hands. But security of energy supply, particularly of petroleum, has been held to justify investment by governments in maintaining strategic reserves and other initiatives. This article argues, however, that petroleum markets are resilient and that the probability of disruptions is slight. Markets can be trusted to satisfy demand without shortages, at affordable prices. In light of structural changes and innovations in petroleum markets, unless the large strategic reserves held by almost all developed countries are actively used to reduce market volatility as a form of public good, maintaining them is difficult to justify.

\section{KEYWORDS}

energy security, petroleum markets, strategic inventories

\section{INTRODUCTION}

Involvement by governments in the area of energy has historically been one of the most extensive and continuous areas of policy making. Whether through regulating the private sector or through ownership of assets, governments across the world have been involved in how energy in its primary forms, such as coal or petroleum, are produced, how it is transformed and distributed, and how it is consumed. In Europe, North America and elsewhere, through either state- owned monopolies or through regulation, government has played key roles in the generation, transmission, and distribution of electricity, and the transportation of natural gas and petroleum via pipelines. While generally refraining from the ownership and operation of upstream primary energy sources, because of concerns over supply security, governments of the developed world have long been involved in strategic storage of petroleum. Security of supply and aspirations to affordability and reliability figure strongly as explanations for government involvement in the energy sector and underscore the premise that markets cannot be trusted to meet policy objectives.

\section{JUSTIFICATIONS OFFERED FOR STATE INVOLVEMENT}

One of the key reasons given for involvement by governments in this sector stems from the natural monopoly argument for utilities such as gas and electricity supply: extensive economies of scale via transmission networks mean that competition is difficult to achieve. This argument has been cited in defence of various regulations and oversight of market structure and behaviour. In the United States, the US Department of Energy (DOE), the Federal Energy Regulatory Commission, and statelevel regulators are authorised to play key roles in the electricity sector, such as determining allowed rates of return on capital. To prevent the abuse of network advantages, in 1887 the US set up the Interstate Commerce Commission to oversee the regulation of common carriers such as gas and oil 
pipelines to promote a level playing field for producers and ultimately distribution companies. Similarly, under the European Union Directive of 2009 (Directive 2009/72/EC) integrated energy firms across Europe were directed to unbundle and restructure transmission and distribution systems into distinct legal entities with independent decision-making mechanisms to promote competition. For Germany's two national champions, E. On and RWE, complying with this EU directive has been a monumental task. In France, although the high voltage grid is independently administered by Réseau de Transport d'Électricité (RTE), it is still owned by Électricité de France S.A.

In the UK the nationalisation of collieries began in 1946 with the creation of the National Coal Board and ended with pit closures and privatisation in the late 1980s. Today in the UK, even with electricity market privatisation and liberalisation, the Department of Energy and Climate Change (DECC), previously the Department of Energy and the Office of Gas and Electricity Markets (OFGEM), continues to play a key role in shaping market behaviour, setting prices, and monitoring profitability while promoting various environmental objectives. Reducing costs through rationalisation has also motivated policymaking. In France, following World War II state involvement in the energy sector began with the nationalisation of coal mining and the natural gas and electricity sectors, through, respectively, Charbonnages de France, Gaz de France (GdF), and Électricité de France (EdF). Today, the French state continues to oversee transactions in gas and electricity markets through the Commission de regulation de l'énergie (CRE), an independent regulatory body. Environmental objectives have also figured strongly in energy policy design. In Germany, the Federal Network Agency has overseen and directed privatised electricity firms in reducing reliance upon coal for electricity generation. One of the original justifications for the European Economic Community back in 1957 was the rationalisation of coal production across member states. In Japan, the Ministry of Economy, Trade and Industry (METI) makes policy with regard to nuclear power, the diversification of primary energy sources, and the encouragement of efficiency, conservation, and decarbonisation.

\section{POLICY INSTRUMENTS}

In general, regulation rather than asset ownership remains the favoured means of achieving such policy objectives as affordability, reliability, and long-term security, although in some countries we see 'mixed models'. In Australia since 1998, both state-owned and private entities generate and sell power into a regulated national grid. On the whole, this approach is applied to the secondary and tertiary sectors rather than primary energy production. In South Africa, although coal mining has been in private hands since the nineteenth century, the integrated electricity sector supplying most of southern Africa continues to be a state-owned monopoly, ESKOM. Within national boundaries, while sectors such as electricity generation and transport tend to be privately owned, they are regulated through both market design and key metrics. Vertical unbundling has been one means of curbing network advantages. But notwithstanding liberalisation and privatisation, the perception of inadequate competition to ensure sufficient investment and fair prices remains. While regulation and ownership has been applied to electricity, for various reasons primary energy exploration, production, refining, and distribution have been treated differently (with the exception of processing and reprocessing of uranium ore and compounds into nuclear fuel). Perhaps because of the international nature of hydrocarbon markets, it has been felt that competitive forces would be sufficient to ensure affordability and safeguard reliability. The break-up of the Standard Oil Trust in the United States back in 1911 is a good example: after it was split into 34 separate entities in order to prevent the abuse of market concentration, affordable supplies were to be promoted through competition (Viscusi, Vernon, \& Harrington, 2018, p. 264). Through achieving the correct market structure, competition would lead to affordable and reliable supplies of petroleum products. 
Although privately owned electricity generation in most countries is regulated as a 'natural monopoly', the sources of primary energy, coal and residual fuel oil, are left to market forces to encourage investment, ensure adequate and reliable supply, and set prices. The 40 -year experiment in government ownership of collieries in the UK between 1948 and 1987 was not a happy one. In privatising and liberalising the electricity sector, much of Europe followed and adopted the UK model for the electricity sector with a strong reliance upon natural gas as the fuel of choice. Though electricity assets were privatised, the provision of natural gas could be left to private entities, as petroleum products are left to the transport sector. Gas Unie of the Netherlands is an interesting exception: although created through partnership between Royal Dutch Shell, Exxon, and the Dutch State, today it is 100 per cent owned by the government. To summarise, while virtually all governments across the developed world at various levels are involved in electricity generation, transmission, and distribution, sometimes through ownership, and utilise various forms of regulation, the sources of primary energy to this key sector remain in private hands. On the whole, when it comes to primary energy, governments appear satisfied to rely upon competitive markets to reliably deliver affordable supplies; but concerns over long-term security remain.

\section{ENERGY SECURITY: THE EXCEPTION}

Although governments in the developed world have generally refrained from involvement in the production of primary energy (coal and petroleum) and have avoided the national oil company business model, as found in the developing world (e.g. Sonangol in Angola, Petrobras in Brazil, Pemex in Mexico), this has not prevented their involvement in the area through concerns over energy security. Ensuring an adequate and reliable supply of petroleum and its products emerged as a strategic issue during World War I, when it became apparent that modern armies and economies require an uninterrupted flow of energy. For the UK, the 1951 Iranian nationalisation of what was once the Anglo-Persian Oil Company (predecessor to British Petroleum) reflected concerns over supply vulnerability. In France, security of supply concerns arising from the 1956 Suez crisis acted as a catalyst to the development of civilian nuclear energy. In the United States, creating a strategic reserve of petroleum against the threat of disruption was first proposed towards the end of World War II. Various proposals were revisited in the 1950s but it was not until the events of 1973-74, what is often called the Arab oil embargo, that the US president made protecting the United States against petroleum supply interruption a matter of policy (Yergin, 1991). Those events and concerns over supply vulnerability led to the construction and maintenance of the US Strategic Petroleum Reserve.

Across the developed world, similar policy initiatives were followed. Today, all countries which are members of the OECD are mandated, in the interests of energy security, by the International Energy Agency (IEA) to hold at least 90 days of consumption in reserve. In Europe, it was under the Council Directive 68/414/EEC of 1968 that members of the then European Economic Community were told to have 90 days of strategic petroleum reserve (SPR) inventories (Directive of the EEC, 1968 ; European Commission, 2014). The IEA defines energy security as the uninterrupted availability of energy sources at an affordable price. Long term it concerns timely investments to supply energy balancing economic development with environmental constraints, while short-term security focuses on the ability of the energy system to react promptly to sudden changes in the supply-demand balance. The 90-day commitment of each IEA member country is based on average daily net imports of the previous calendar year. SPRs are designed to provide a cushion in the event of an energy supply crisis. SPRs typically comprise only crude oil and exclude stockpiles of gasoline and other refined products. Among the 36 members of the OECD, in recent years the volume of crude oil in SPRs has been relatively constant at about $3.05 \mathrm{bn}$ barrels. The US makes up the largest component 
of those OECD barrels in storage, having about $695 \mathrm{~m}$ barrels. Japan has the second largest SPR stockpiles with roughly $324 \mathrm{~m}$ barrels. South Korea is a close third with $286 \mathrm{~m}$ barrels emergency reserves held by government and industry. France, Germany, and Spain have, respectively, $65 \mathrm{~m}$, $70 \mathrm{~m}$, and $120 \mathrm{~m}$ barrels in storage. In general, we see that for both large producers of crude oil as well as those which are heavily reliant upon imports there is a commitment to what is termed a strategic storage. In total, according to the IEA (2019), approximately $4.1 \mathrm{bn}$ barrels in strategic storage held by members of the OECD.

What is the cost of maintaining such strategic reserves? Providing even a few months of import protection for an advanced economy is expensive. As a benchmark we can use some estimates for maintaining the American SPR. For the US, to date about $\$ 5 b n$ has been spent on the facility and over $\$ 20 \mathrm{bn}$ on filling it with crude oil. Maintaining and operating the various underground salt domes used for storage has added approximately 20 per cent to the cost of crude oil in storage. Scaling up from the US data implies that keeping about $4 \mathrm{bn}$ barrels in storage has a cost exceeding $\$ 28 \mathrm{bn}$ while the value of oil in storage may exceed $\$ 100 \mathrm{bn}$. In addition, there is the opportunity cost of money used for oil in the ground as opposed to being in the bank or for reducing the national fiscal deficit. As a rough calculation for the United States, although oil in reserve has been acquired at various historic prices, marking-to-market at today's $\$ 60$ per barrel price, and on the assumption of a cost of capital of 3 per cent, the SPR of the US has an opportunity cost exceeding $\$ 1.2 \mathrm{bn}$ per annum. For the members of the OECD as a whole, pro-rating suggests an opportunity cost of capital of nearly $\$ 7 \mathrm{bn}$. In addition to the opportunity cost of capital, there is the opportunity cost of not operating an SPR in a commercial manner, as is the practice of major integrated oil companies with storage facilities for crude oil, petroleum products, and natural gas. SPR facilities may be 'cycled' with daily injections or withdrawals in order to take advantage of differences between actual storage costs (cost of carry) and the cost of hedging in futures markets. Given the amount of oil in storage across the developed world, we can observe that there is a large opportunity cost to not operating such facilities in a commercial manner. Altogether, the above magnitudes raise two questions: first, if we compare costs with benefits, are such expenditure and opportunity costs justified? Second, based upon our knowledge of markets, is storage really needed?

\section{RATIONALE}

Given the costs set out above, it is sensible to inquire whether such expenditure is justified. Interrupting the oil supply of Germany or Japan for even a few weeks would have a devastating impact upon economic output and activity. Import dependence and supply insecurity continue to be common justifications for governments acting as 'suppliers of last resort'. But when members of the OECD began stockpiling petroleum reserves back in the 1970s, oil markets were very different. Most crude oil and oil products were sold under long-term contracts; exchange trading of this key commodity using futures and options had hardly begun. Critically, before the introduction of petroleum futures on the New York Mercantile Exchange in 1974, there was almost no scope for hedging exposure to changing prices as we would expect under a supply disruption. Today, across the globe regulated exchanges offer liquid markets in futures and options, which may be used to transform and mitigate exposure to changes in demand and supply of oil and energy-related products.

In addition to financial innovations, we see that today's supplies of crude oil and oil products are geographically more diversified. Although the world uses about 40 per cent more petroleum daily than it did in 1975, reliance upon OPEC production has fallen: from slightly over 40 per cent in 1980, today's production from OPEC members has fallen to about 37 per cent of total global production 
(see Figure 1). Moreover, OPEC members now consume more of their own production because of their own economic development, reducing their net contribution to global markets to around 30 per cent.

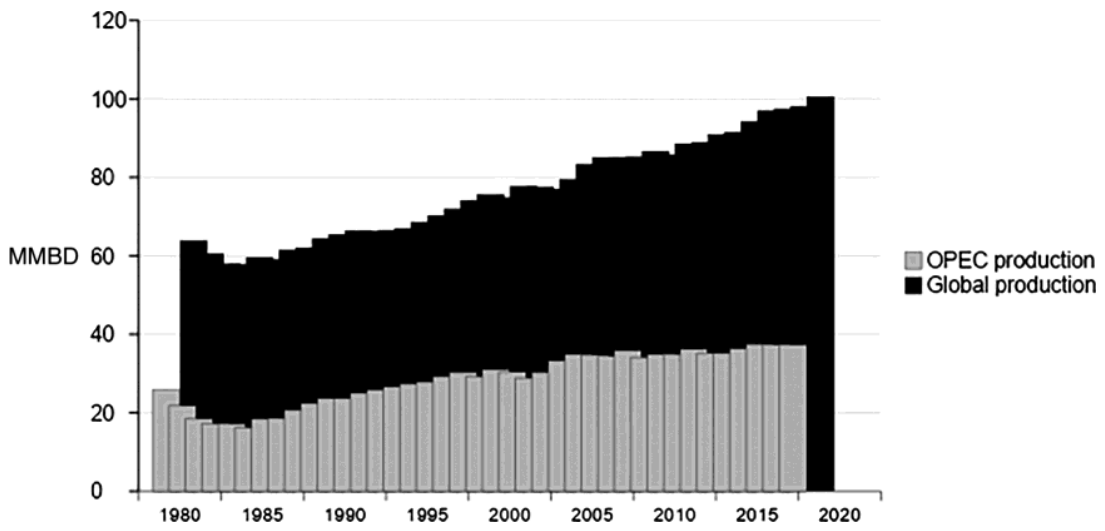

FIGURE 1 OPEC's declining share of global petroleum production (millions of barrels per day), 1980-2018. Source: US DOE-EIA.

Fears of supply insecurity were also motivated by the historic concerns that soon the world's reserves of crude oil would be exhausted. Such notions gained traction in the 1970s and informed a host of polices across the developed world, such as promoting synthetic fuels in the United States and mandating fuel efficiency standards for motor cars. In the 1990s, it was imagined that oil production had 'peaked'. Two decades later, we have entire new regions of the world such as Angola, Brazil, Uganda, Mozambique, the deep offshore, and the Arctic contributing to global supply. New exploration frontiers have opened in Africa and South America. In the United States, though it had been forecast by US DOE in 1980 that oil production from the 'Lower 48' would decline inexorably, since 2010 we have seen a dramatic reversal of this trend. A revolution in exploration and production driven by such technological advances as directional drilling and the recovery of deposits from 'tight seams' through hydraulic fracturing have substantially enhanced the supply position and the energy security of the United States. On the whole, since the time various nations built and began strategic stockpiling, supplies have become much more diversified. Improved efficiency, conservation, and renewable energy have made supplies more diversified and markets more resilient.

\section{DEFINING AND MEASURING SUPPLY INSECURITY}

Notwithstanding the manifest changes to the basic conditions of supply and demand, the structure, and the behaviour of petroleum markets in the last half-century, policymakers still promote the idea that we face supply insecurity as one of several justifications for government involvement in primary markets. Although governments across the developed world have not engaged in the exploration and production of primary resources, maintaining strategic reserves has become a central plank of policy. In the United States, one justification for supporting domestic crop-based ethanol as an additive in transportation fuels was that it was more secure than importing oil from overseas. Indeed, one of the latest arguments for promoting renewable energy is that it reduces dependence upon imported supplies. According to the partially EU-funded organisation Transport \& Environment, self-described as 'Europe's leading clean transport campaign group', ${ }^{1}$ increasing dependence upon imported petroleum from geo- politically unstable regions is a key rationale for the promotion for the electrification of road transport (Transport \& Environment, 2016). But how 
should 'supply insecurity' be measured? In academic research, the focus tends towards the development and calibration of metrics of dependence upon imports and the scope for mitigation (Ang, Choong, \& Ng, 2015; Winzer, 2011). Some researchers look at the balance of supply and demand, or consider resource estimates, the ratio of imports to domestic production, or measures of economic structure such as producer concentration, energy intensiveness, price elasticity, and market conditions (Fygin \& Satkin, 2004; Cherp \& Jewel, 2011). Examining the probability of a supply disruption actually happening is rarely considered.

At official levels, in order to analyse petroleum market insecurity, the IEA introduced in 2011 its Model of Short-Term Energy Security (MOSES) for primary energy sources and secondary fuels among IEA members (Jewell, 2011). MOSES examines short-term energy security, defined as vulnerability to physical disruptions that can last for days or weeks. Using an energy systems approach, MOSES identifies a set of indicators for external risks (from energy imports) and for domestic risks (from transformation and distribution) as well as for resilience - a country's capacity to accommodate different types of disruptions. By using the IEA's MOSES model, energy security may be ranked according to five categories, from most to least secure. MOSES offers a framework for conceptualising policy discussions on energy security: it depicts basic conditions of supply and demand at country level and facilitates inter-country comparisons. If a country wished to change basic conditions, the model may be used to inform policy making. Like some other metrics, the focus of MOSES is upon the short-term impact of volumetric loss to supply and, in some instances, upon the ability to mitigate or absorb the loss. Whether we are referring to the many academic efforts or to the work of official bodies, however, the probability of a supply disruption is not addressed.

\section{SHORTCOMINGS IN MEASURING SECURITY}

Such modelling approaches are interesting and tell us much about vulnerability and resilience, but they do not tell us about the probability of a supply disruption occurring. These models focus upon exposure to disruption and the ability of a nation or region to absorb the impact of such an event, but not the chances that it may happen (Asia Pacific Energy Research Centre, 2007). That these modelling efforts do not address the probability of a disruption is curious. Even before the key changes to global petroleum markets transpired, the justifications for maintaining a strategic reserve should arguably have included the probability of a disruption taking place. In the insurance and finance literature, three parameters are used to characterise a risk:

- the exposure to potential loss if the event occurs;

- the scope for mitigation or loss absorption within a specified time frame; and

- the probability of the event happening.

The probability of supply disruption is important because we repeatedly see major events in oil markets that appear capable of interrupting physical supply and affecting prices, but markets absorb the shocks and remain resilient. In 2016 we saw sabotage in Kirkuk, a strike in Kuwait, the Canadian wildfire, Nigeria's force majeure, export blockage in Libya, Colombian pipeline disruptions, Italy's Val d'Agri shut down, and fire at Brazil's Barracuda-Caratinga site. These were all serious events; none of them, however, led to disruptions or affected oil prices, which continued to trade in a range of \$2654 per barrel, as shown in Figure 2. Similar observations may be made for 2017, when despite OPEC's production cuts market liquidity was not affected (IEA, 2018). In 2018 we saw Venezuela attach the assets of Conoco Petroleum and a wave of political protests across Iran. In 2019 sanctions against Iran have been increased and tankers have been interdicted upon the high seas. Today, Venezuela produces about one-third of the oil it pumped in the 1970s, for reasons that are wellknown. Theoretical vulnerability notwithstanding, if there were a reasonable possibility of oil supply 
disruption taking place, one would imagine that prices for this vital commodity would be a lot higher; but as of August 2019, Brent is trading around $\$ 60$.

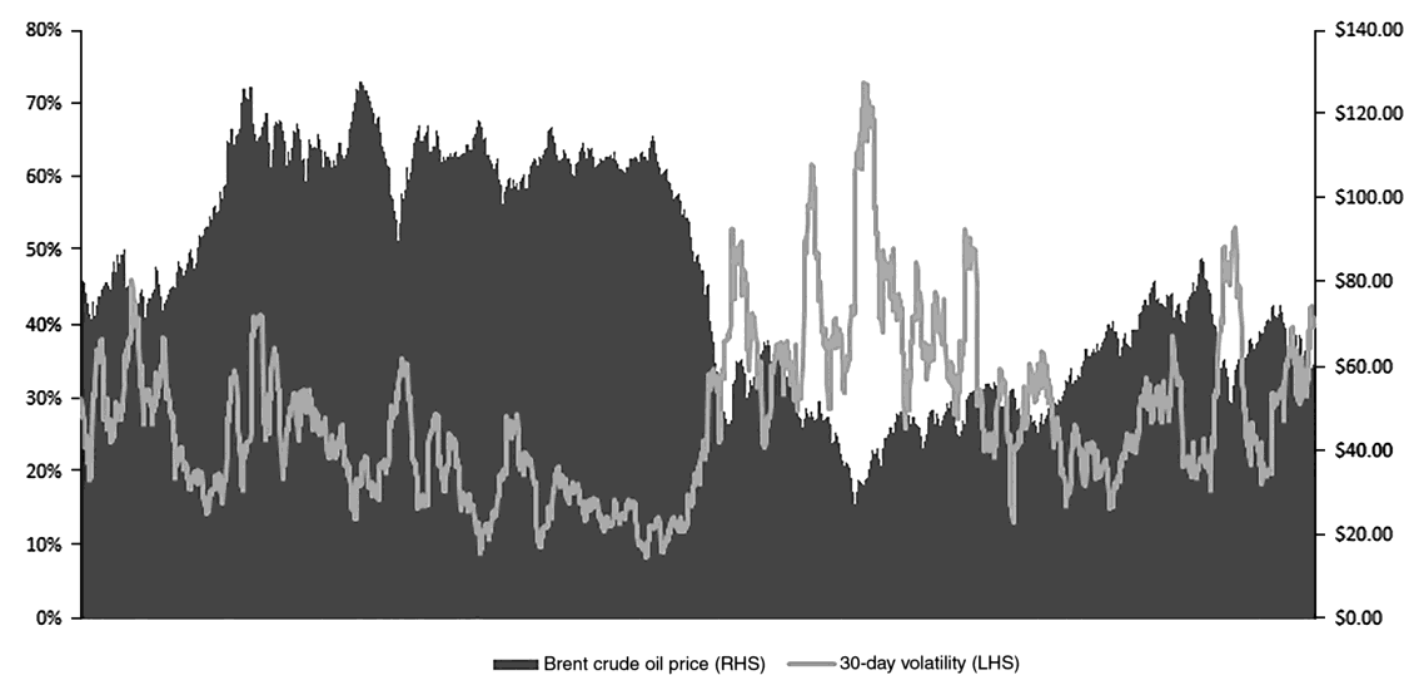

FIGURE 2 Crude oil price and volatility, 1 January 2010-26 August 2019. Source: US DOE - EIA.

In retrospect, it is also interesting to note that when physical disruptions to supply took place, government intervention played a role. The supply disruption in the summer of 1951 resulted from an orchestrated response to the Iranian nationalisation of its oil industry. A global boycott of its production removed $19 \mathrm{~m}$ barrels per month of production from markets. The effects of the boycott were exacerbated by the US domestic price controls in place during the Korean War (Hamilton, 2013). It has also been argued that the effect of the 1973-74 Arab oil embargo, including the long queues for transportation fuels in major US cities at the time, resulted from the Nixon administration's imposition of price controls and the misallocation of transportation fuels between petroleum administrative districts by the US Department of Energy. Recent and historical events show the resilience of global petroleum markets. On the whole, during those historic occasions when markets were less resilient, while supplies were physically affected, government policies played a pivotal role in market disruption.

\section{THE PROBABILITY OF SUPPLY DISRUPTION}

The United Kingdom, like other countries of the OECD, follows the IEA's 90-day import replacement guidance on minimum stockholding requirements. But is this amount sufficient? Or is it excessive? The various official and academic models facilitate comparing the costs with the benefits of having a reserve to augment supply if and when a disruption has taken place; but, as we have seen, such events are exceedingly rare. Tumultuous events, as have been chronicled, have taken place - but international petroleum markets carried on with prices equilibrating supply and demand. Not examining the probability of disruption seems questionable; but given the infrequency of supply disruptions, as we have documented, how may we construct a probability distribution that allows us to compare the considerable costs with the expected benefits of avoiding physical disruption?

In a recent jointly written article, I seek to overcome this key obstacle by extracting the information found in traded option markets (Haar \& Haar, 2019). We calculate the probability of disruption into the measurement of energy security, deriving probabilities from regularly traded option prices 
(Jackwerth \& Rubenstein, 1996; Jackwerth, 2000). Usefully, the forward-looking nature of option markets embodies the views of participants about prices in the future. Markets for crude oil, petroleum products, and natural gas hold the attention of countless agents seeking to secure supplies, hedge exposures, speculate, and take advantage of anomalies through arbitrage. We argue that option prices provide better insights into energy security and the threat of disruption than the metrics and models currently used by policymakers (Breeden \& Litzenberger, 1978).

To explain our method: traders put a premium on options that are deeply in the money, such as the right to purchase crude oil at $\$ 50$ when the market is trading at $\$ 60$, or to sell crude oil at $\$ 70$ when the market is trading at $\$ 60$. From the size of these premiums for deeply in-the-money and out-ofthe money options, we can derive probabilities across a distribution of future prices. If oil market disruptions were anticipated, then greater probability would be attached to extreme prices, as calculated using well-known option pricing formulas. How much one is willing to pay for out- of-themoney or deeply in-the-money option prices reflects probability attached to such events.

Rather than relying upon 'expert' opinion, we use the information embedded in traded option prices representing the collective views of millions of buyers, sellers, and oil traders globally. We use published data from the International Commodity Exchange (ICE) on option prices and volatilities for the crude oil benchmark, Brent, to determine the probabilities attached by the world's traders to extreme prices embedded in option prices, allowing us to infer the chances of supply-demand imbalances.

\section{THREE CASE STUDIES}

Reflecting upon whether maintaining strategic reserves is needed, the perceptions of traders are examined through the probabilities embedded in option prices, during three periods when pundits and 'experts' conjectured that prices might rise inexorably. Using this method, we compute riskneutral probability histograms for the periods shown in Table 1. From the probability histograms we can determine the market's expectation of future prices.

Beginning with the implied risk-neutral histogram for the Brent crude oil prices during the First Gulf War, we see from Figure 3 that, over the dates shown, the market expectation of future prices was slightly skewed to the left. In the views of the trading community, there was a greater probability of prices falling. Although price volatility (a measure calculated from a rolling 30-day standard deviation of percentage change in price annualised to a business year of 252 trading days) at the time was high (77 per cent), as reported in Table 1 the expected price for the year was around $\$ 26$ per barrel. There were many extreme scenarios of how what was the First Gulf War would unfold (Lee, 1991). But market participants pricing options did not believe disruptions were likely: the probability of greater prices was smaller than the probability of prices softening, and the probability of extremely low or high prices was much lower than the expected price of $\$ 26$.

As shown in Figure 3, the probabilities ascribed to tail events became smaller over time. Travelling forward in time from the front of our three-dimensional graph to the back, the total probability of extreme high prices decreased dramatically. The day after the United States and its allies attacked Iraq, oil prices in London and New York plunged an unprecedented $\$ 10.56$ a barrel to $\$ 21.44$, ten cents below its price the day before Iraq invaded Kuwait. The price remained in this range throughout the conflict. Market participants correctly discounted any effect upon oil prices from the conflict.

We next turn to the 2008 financial crisis, the results of which are shown in Figure 4. Moving forward in time, we see that the total probability of extremely high prices decreased and the overall 
distribution of expected prices flattened. Emergency policies from central banks had not commenced and the potential for shale oil in the United States was as yet unknown. As the year progressed the distribution grew flatter, with growing market uncertainty. Although the shock waves from the financial crisis were just beginning to reverberate, the probability attached to extreme scenarios such as demand collapsing grew smaller. As summarised in Table 1, according to constructed probability distributions, the mean expectation was that oil prices would remain at just over $\$ 90$ per barrel. As reflected in markets, oil prices during the financial crisis were high, but volatility only increased sharply toward the end of the year. It reached 103 per cent for Brent crude on 16 December, as shown in the flattening distribution in Figure 4. Although the widening financial crisis added to oil market risks, option prices suggested market participants were still anticipating reliable supplies at prevailing price levels: this again proved prescient. Even with the ensuing banking collapses and the sovereign debt crisis, oil markets continued to function.

TABLE 1 Case studies and results

\begin{tabular}{|l|l|l|l|}
\hline Metrics/case studies & First Gulf War, 1990 & 2008 financial crisis & Arab Spring, 2011 \\
\hline Data & $15.06 .90-01.03 .91$ & $02.01 .08-31.12 .08$ & $01.04 .11-30.06 .11$ \\
\hline E (Prices) & $\$ 26,32$ & $\$ 94.59$ & $\$ 115.38$ \\
\hline Historic volatility & $76.87 \%$ & $42.73 \%$ & $31.73 \%$ \\
\hline Minimum & $\$ 18.71$ & $\$ 67.86$ & $\$ 81.91$ \\
\hline Maximum & $\$ 34.75$ & $\$ 126.03$ & $\$ 152.12$ \\
\hline
\end{tabular}

During the Arab Spring of 2011, the average prices of crude oil were high while volatility was moderate. As the crisis began, by December 2010 some analysts were predicting that the demonstrations in Tunisia would lead to supply-chain disruptions and a sharp rise in oil prices. As unrest spread to other countries, the threat of interruption gained credibility. The IEA coordinated a drawdown of strategic reserves to calm markets. The threat of civil unrest spreading to the Gulf, for example, was raised and calamitous scenarios were suggested.

There were, however, a few dissenting opinions. A report from the Oxford Institute for Energy Studies warned against alarmism, arguing that oil markets are resilient and that the basic conditions of supply and demand were unlikely to change (Darbouche \& Fattouh, 2011). A paper on the Arab uprising from Chatham House, a British think tank, drew similar conclusions (Stevens, 2012). Interestingly, from the probabilities derived from option prices, we see in Figure 5 a flattish distribution reflecting a divergence of views. The distribution is flatter than those in Figures 3 and 4 because market participants attached greater probabilities to prices becoming both higher and lower. According to option markets, the median view was for prices to remain around $\$ 120$ per barrel. We see throughout the period that only slight weight was given to prices going even higher, but, like the dissenting voices, the market appears not to have taken seriously the possibility of extreme prices. Petroleum market traders were not attaching large probabilities to extreme events. There were probabilities attached to higher prices; the distribution was flattish, but the median of the distribution still had the greatest mass. In contrast to the doomsayers, the market perception as that petroleum supply and demand were sufficiently resilient to weather the various events of 2011 . 


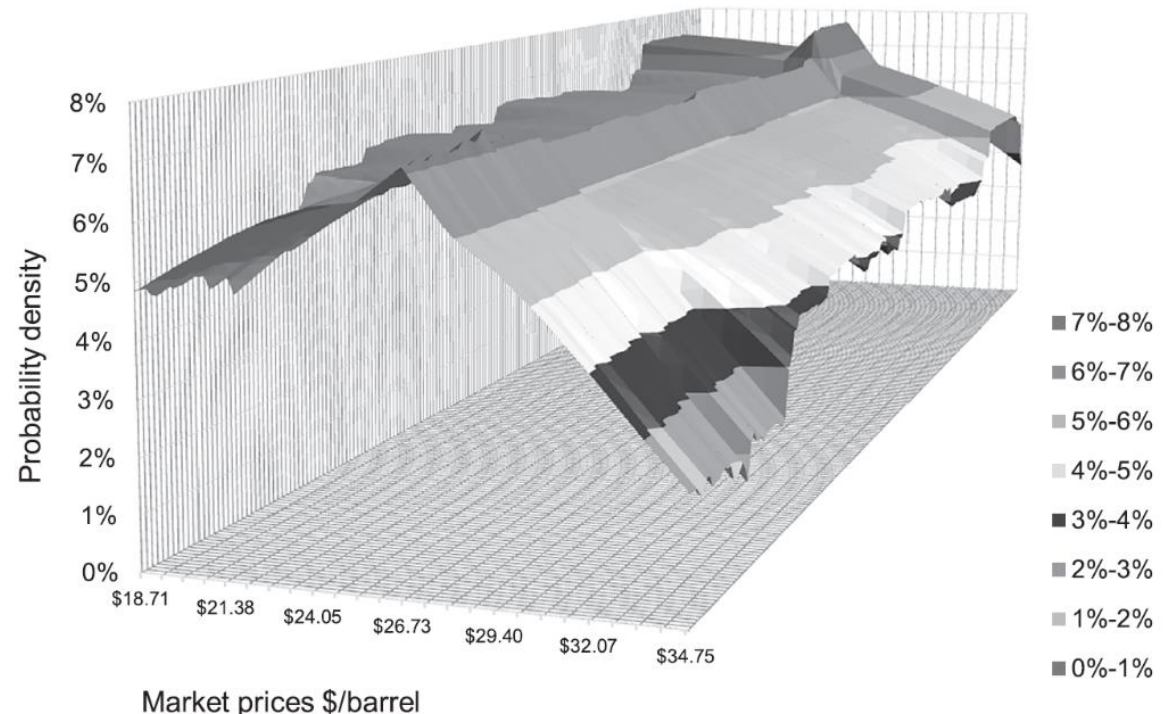

FIGURE 3 Implied risk-neutral histogram for Brent crude prices, First Gulf War (15 June 1990-1 March 1991).

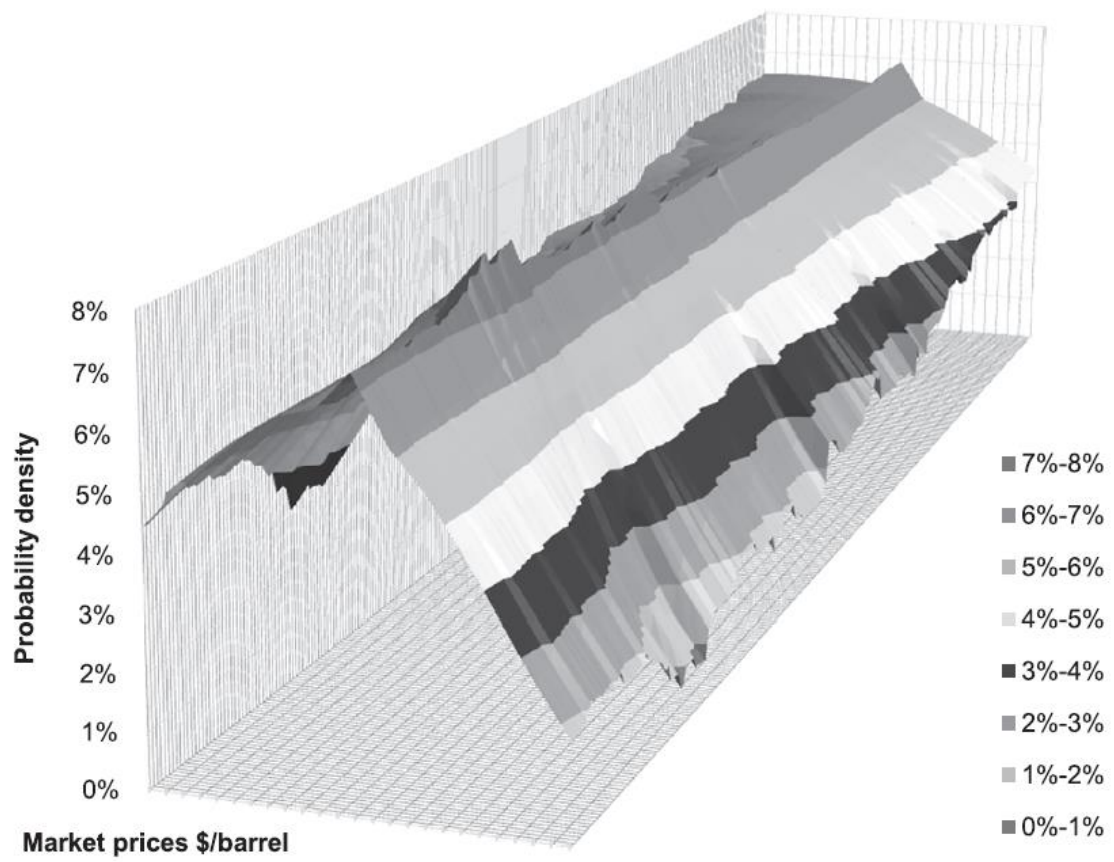

FIGURE 4 Implied risk-neutral histogram for Brent crude prices, 2008 financial crisis (2 January-31 December 2008)

Our examination of probabilities derived from option prices is illustrative. They prove neither that markets are always resilient nor that disruptions cannot take place. But the results support the following points:

- In the periods examined, markets were not anticipating extremes as might occur under a disruption scenario 
- For traded markets such as crude oil and petroleum products, the challenge of constructing probability distributions on rare events may be overcome using information embedded in traded option prices.

- From a policymaking perspective, examining a potential loss if the event happens and the scope for mitigation or loss absorption, without including the probability of the event taking place, is not helpful and may lead to questionable programmes and expenditures.

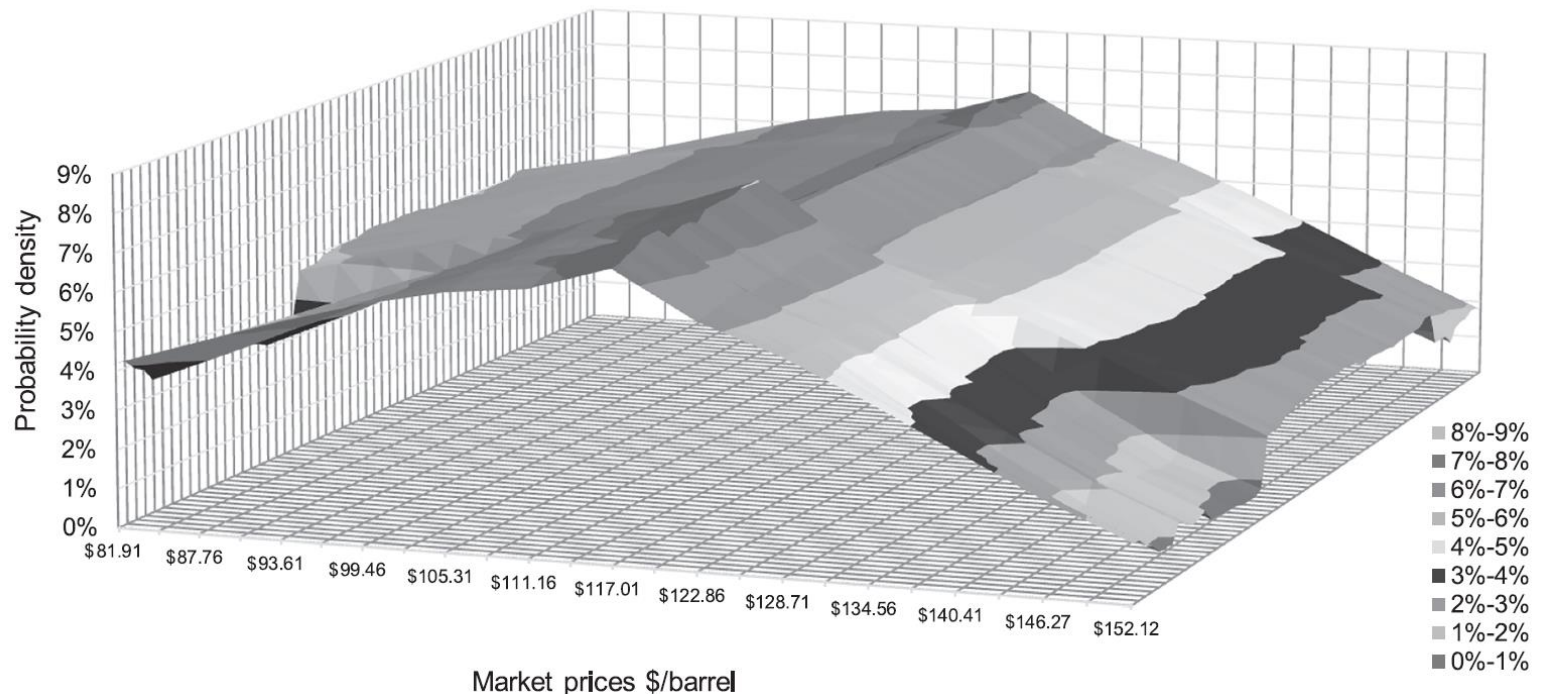

FIGURE 5 Implied risk-neutral histogram for Brent crude prices, Arab Spring (1 April30 June 2011).

As shown in Table 1, markets did not expect price spikes, and the prices to which even small probability events were ascribed were not outliers. Arguably, according to forward-looking price estimates obtained from the risk-neutral density functions, markets were not anticipating supply disruptions, and proved accurate: participants correctly foresaw that market shortfalls or disruptions were unlikely. Even with output from some producers falling, in the periods examined markets were not anticipating price levels consistent with disruptions or other forms of supply insecurity. If, during these volatile situations, traded markets attached only small probabilities to price extremes as might occur through supply disruption, it seems fair to ask whether maintaining strategic stockpiles is justified. If, during these three historical cases, the case for maintaining strategic reserves was weak, should developed countries like those of the OECD continue their use? Fundamentally, are oil markets prone to disruption? Do we really face energy insecurity, as commonly asserted? From supporting expensive bio-fuels to subsidising renewable energy and mandating efficiency standards for appliances, the existence of energy insecurity is commonly cited in defence of a host of government policies above and beyond the direct costs of maintaining a strategic reserve. But are they needed? Can security of supply be left to the market?

\section{STRATEGIC RESERVES AS MARKET STABILISERS}

National storage of crude oil is widely seen as precautionary public good designed to mitigate the effect of severe and sustained import disruption. Yet petroleum products are both excludable and rivalrous in nature. In many countries, privately owned crude oil inventories may be almost as large as strategic volumes. But if markets are resilient and the probability of physical disruption slight, is there an argument for using strategic reserves across the developed world to reduce market volatility? Allowing markets to equilibrate at much higher prices, for example, might be too costly, 
with allocative and redistributive effects. Is there a role for government in reducing or eliminating risk even if the probability of disruption and extreme price scenarios is remote? Like requiring medical insurance or mandating saving for retirement, might expenditure on storage be justified to avoid free-riders? May negative externalities arise through insufficient management of risk? Is there a case for reducing risk in petroleum markets, and how might it be measured?

Although strategic stockpiling has been undertaken to redress the effects of import disruptions, over the years it has been used instead for price stabilisation during such events as the First Gulf War and the collapse of the Libyan regime in 2011, when the IEA coordinated a global destocking (Financial Times, 2011). Even extreme weather such as hurricanes in the Gulf of Mexico have led to strategic reserves being used to calm markets. As a policy decision, however, the provision of risk management by governments to calm markets in this fashion is curious because oil producers, consumers, and traders have available liquid global markets in options and futures to hedge exposures and manage risks. If petroleum markets are resilient and robust to disruptions, might using a strategic reserve to dampen market volatility - making markets more predictable and reducing or even eliminating the cost of hedging - be justified as a public good?

Formally, the decision on how much of a public good should be produced requires finding the level of production that equates marginal social benefits with marginal social costs (Samuelson, 1954). Holding physical storage at a known price is an alternative to risk-managing the exposure using options. In Figure 6 we compare the marginal benefit from risk reduction using the prices of European call options with the approximate costs per annum of managing a strategic reserve in size equal to that of the United States. As the figure indicates, unless volatility is reduced by about 20 per cent (from an assumed volatility of 50 per cent to about 40 per cent), the costs of maintaining such a reserve (shown by the dotted line) would not be covered. One would need to see market volatility reduced from 50 per cent (by assumption) to 30 per cent, or a nearly 40 per cent reduction in market risk for the benefits of volatility reduction (as shown by the solid line) to exceed the cost of risk reduction (as shown by the dashed line) to justify the investment in maintaining an SPR. And this would occur only if a SPR were used presciently, selling when the market is tightening and purchasing when the market is loosening (Leiby \& Bowman, 2006). Although the results can be recalibrated to a different assumed initial volatility, these results reflect historic volatility values. Not trusting markets to ensure security of supply, the nations of the OECD began stockpiling petroleum after the 1973-74 oil crisis with the creation of the International Energy Agency (IEA) which had energy security as its core activity. The International Energy Program (IEP) contained in the IEA's governing treaty commits member countries to maintain emergency oil reserves equivalent to at least 90 days of net oil imports (DECC, 2015). Nearly half a century ago, the structure and behaviour of markets were very different; for example, the scope for managing price exposure through futures and options did not exist. But given the low probabilities attached to extreme prices during extreme situations as well as the scope for undertaking private risk management through using futures and options, the considerable expenditure required for maintaining reserves along with the opportunity cost seems very difficult to justify. Energy security is an important issue, but the case for government involvement is not robust. 


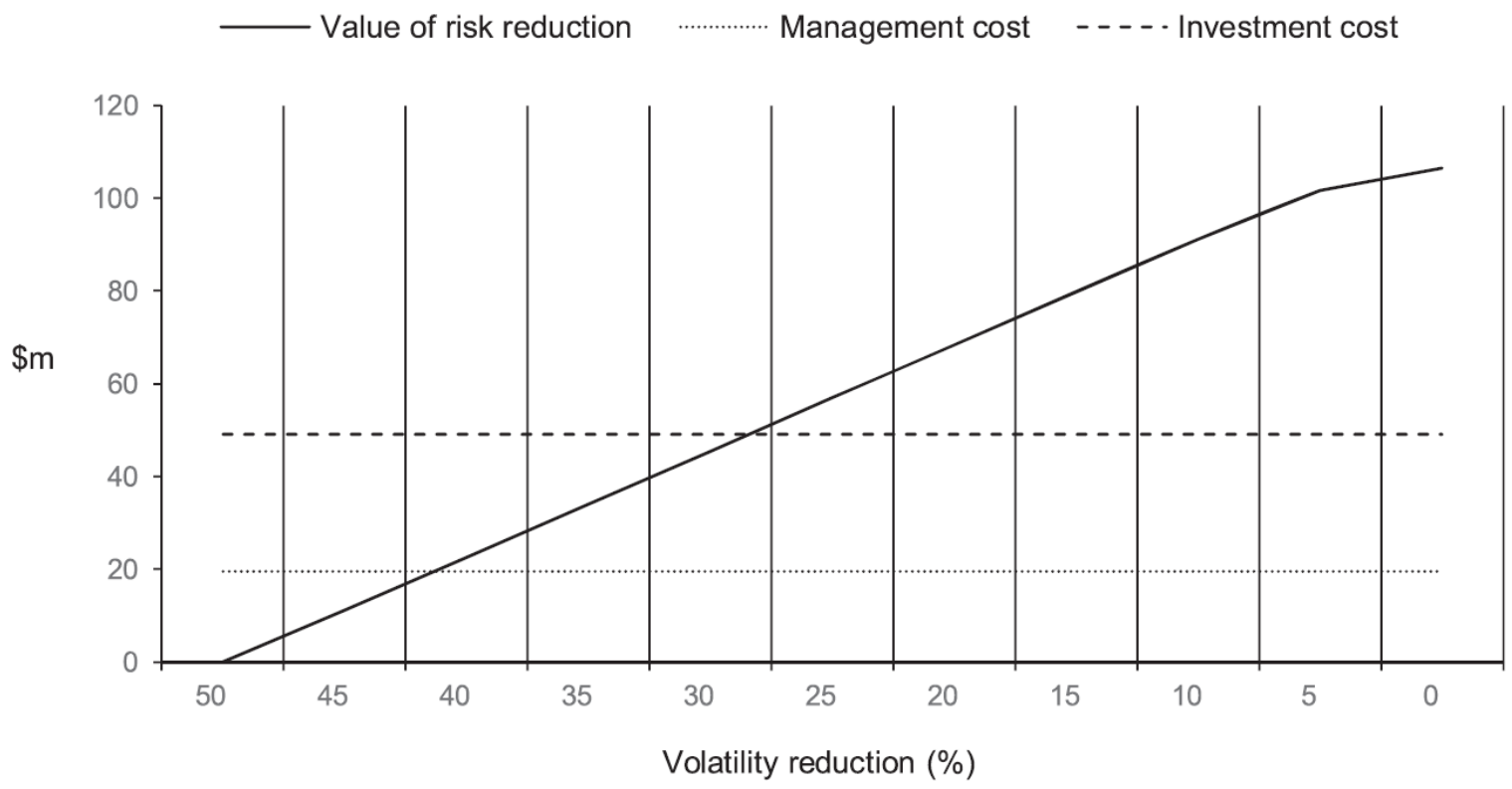

FIGURE 6 Benefits of risk reduction versus management and investment costs of the US Strategic Reserve on an annual basis. Source: Haar \& Haar (2019).

\section{CONCLUSION}

We have seen that the case for government involvement in protecting energy security through strategic storage is weak. Markets are resilient even under extreme circumstances. Given the scope for privately transforming and managing exposure to petroleum markets, constructing a 'public good' argument, as economists define the term, is not a strong one. From airlines to car manufacturers to oil companies, everyone can manage exposure to oil prices according to the riskreward tolerance of their respective shareholders. There is no reason to believe that the benefits of risk management may be under-consumed, creating social costs and externalities. There might be a case for maintaining strategic stockpiles if they were used in a coordinated manner to dampen market volatility; but, apart from the practical challenges, the gains would need to be large. One might argue that the existence of such reserves helps to deter certain oil-producing countries from seeking to exert their market power, but this presumes some degree of market power, which is disputable.

Moreover, to turn to the downsides, having strategic reserves may even contribute to moral hazard because parties which should manage their own risks become free-riders, like financial institutions relying on a central bank as a 'lender of last resort'. This phenomenon has been observed with respect to agricultural futures in the United States, where, despite great scope for hedging of exposures, farmers prefer to rely upon price supports from the US Department of Agriculture (Kirwan, 2009; Riedl, 2011). Petroleum markets, like the world itself, will remain a risky place. Given the historical resilience of petroleum markets to severe shocks, the scope for private parties to manage their own risks, and the costs of maintaining strategic reserves, hard- pressed voters across the developed world should ask whether the money could be better spent. Carefully liquidating reserves might even be used to reduce national debts. Lastly, although difficult to imagine, under an extreme scenario of true long-term disruption to supplies, a stockpile lasting a few months would hardy make a difference. 


\section{ENDNOTE}

${ }^{1}$ https://www.transportenvironment.org/about-us (accessed 8 September 2019).

\section{REFERENCES}

Ang, B. W., Choong, W. L., \& Ng, T. S. (2015). Energy security: Definitions, dimensions and indexes. Renewable and Sustainable Energy Reviews, 42, 1077-1093.

Asia Pacific Energy Research Centre (2007). A Quest for Energy Security in the 21st Century: Resources and Constraints. Tokyo: Asia Pacific Energy Research Centre. https://aperc.ieej.or.jp/file/2010/9/26/APERC_2007_A_Quest_for_Energy_Security.pdf (accessed 9 September 2019).

Breeden, D., \& Litzenberger, R. (1978). Prices for state-contingent claims: Some estimates and applications. Journal of Business, 51, 621-651.

Cherp, A., \& Jewel, J. (2011). The three perspectives on energy security: Intellectual history, disciplinary roots and the potential for integration. Environmental Sustainability, 3, 1-11.

Darbouche, H., \& Fattouh, B. (2011). The Implications of the Arab Uprising for Oil and Gas Markets. Oxford: Oxford Institute for Energy Studies.

European Commission (2014). In-depth study of European Energy Security, Accompanying the document - Communication from the Commission to the Council and the European Parliament: European energy security strategy, 2014. Brussels: European Commission. https://ec.europa.eu/energy/sites/ener/files/documents/20140528_energy_security_study.pdf (accessed 9 September 2019).

Financial Times (2011). 23 June. https://www.ft.com/content/f679b6a0-9dae-11e0$\underline{\text { b30c00144feabdc0 }}$

Fygin, M., \& Satkin, R. (2004). The oil reserves to production ratio and its proper interpretation. Natural Resources Research, 13(1), 57-61.

Haar, L., \& Haar, L. N. (2019). A financial option perspective on energy security and strategic storage. Energy Strategy Reviews, 25, 65-74.

Hamilton, J. D. (2013). Historical oil shocks. In R. E. Parker, \& R. M. Whaples (Eds.), Routledge Handbook of Major Events in Economic History (pp. 239-265). New York: Routledge Taylor and Francis Group.

IEA (International Energy Agency) (2018). World Energy Investment 2018. Paris: IEA.

IEA (2019). Closing oil stock levels in days of net imports. Statistics Resources. https://www.iea.org/ netimports/ (accessed 12 September 2019).

Jackwerth, J. C. (2000). Recovering risk aversion from option prices and realized returns. Review of Financial Studies, 13(2), 433-451.

Jackwerth, J. C., \& Rubenstein, M. (1996). Recovering probability distributions from option prices. Journal of Finance, 51, 1611-1631.

Jewell, J. (2011). The IEA Model of Short-term Energy Security (MOSES): Primary Energy Sources and Secondary Fuels. Working Paper. Paris: IEA. 
https://www.iea.org/publications/freepublications/publication/moses_paper.pdf (accessed 9 September 2019).

Kirwan, B. E. (2009). The incidence of U.S. agricultural subsidies on farmland rental rates. Journal of Political Economy, 117(1), 138-164.

Lee, P. (1991). Impact of the Gulf War: Crude plunges; Gasoline prices to dealers cut: Energy: The movement defies predictions. But analysts warn that negative news could quickly reverse the market's course. Los Angeles Times, 18 January. https://www.latimes.com/archives/la-xpm-1991-0118-fi-102-story.html (accessed 9 September 2019).

Leiby, P., \& Bowman, D. (2006). Economic Benefits of Expanded Strategic Petroleum Reserve Size or Drawdown Capability. Final Report, 31 December. ORNL/TM-2006/5. Oak Ridge, TN: Oak Ridge National Laboratory.

Riedl, B. M. (2011). Farm Subsidies are Ripe for Reform. 29 March. Washington, DC: Heritage Foundation. http://www.heritage.org/social-security/commentary/farm-subsidies-are-ripe-reform (accessed 9 September 2019).

Samuelson, P. A. (1954). The pure theory of public expenditure. Review of Economics and Statistics, 36(4), 387-389.

Stevens, P. (2012). The Arab Uprisings and the International Oil Market. Briefing Paper EERG 2012/03. London: Chatham House.

https://www.chathamhouse.org/sites/files/chathamhouse/public/Research/Energy\%2C\% 20Environ ment\%20and\%20Development/bp0212stevens.pdf (accessed 9 September 2019).

Transport \& Environment (2016). Europe Increasingly Dependent on Risky Oil Imports. Brussels: Transport \& Environment. Briefing, July. https://www.transportenvironment.org/sites/te/files/publications/2016_07_ Briefing_Europe_increasingly_dependent_risky_oil_FINAL_0.pdf (accessed 9 September 2019).

Viscusi, W. K., Vernon, J. M., \& Harrington, J. E. (2018). Economics of Regulation and Antitrust (4th ed.). London: MIT Press.

Winzer, C. (2011). Conceptualizing Energy Security. EPRG Working Paper 1123. Cambridge: Electric Power Research Group, Cambridge University.

Yergin, D. (1991). The Prize: The Epic Quest for Oil, Money and Power. New York: Free Press.

\section{EUROPEAN UNION LEGISLATION CITED}

Directive of 1968 (68/414/EEC). https://publications.europa.eu/en/publication-detail//publication/2cb8ce18- ff8c-4cf2-8708-9a43206a10f9/language-en (accessed 12 September 2019). Directive of 2009 (Directive 2009/72/EC). https://eur-lex.europa.eu/legalcontent/EN/ALL/?uri=CELEX\% 3A32009L0072 (accessed 9 September 2019). 